\title{
Effect of Work Culture and Leadership Against Employee Commitments In The Industrial Revolution 4.0 Era
}

\author{
Pandapotan Sitompul, Suparno Eko Widodo, R. Madhakomala
}

\begin{abstract}
The era of revolution 4.0 is an era where almost all data processing transactions are connected to each other, so the decisions taken by a leader in the work culture of employees can be easily monitored. The objective of this research is to study the effect of work culture and leadership on employee commitment. The process of research was conducted at PT. Astra Agro Lestari Tbk. it has used case study methode. The samples of research were 105 employee of PT Astra Agro Lestari Tbk. that were selected in a simple random sampling. The results of finding are: (1) there is a positively direct effect of work culture on employee commitment, (2) there is a positively direct effect of leadership on employee commitment (3) there is a positive direct effect of work culture and leadership together on employee commitment. Referring to these findings, the researcher could conclude that employee commitment is positively affected by work culture and leadership. Therefore, to maintain employee commitment, the organization has to apply the work culture and leadership. Finally, it should be concluded that work culture and leadership should be taken into consideration in generating the employee commitment.
\end{abstract}

Keywords: Employee Commitment, Work Culture, and Leadership of Industrial Revolution 4.0

\section{INTRODUCTION}

Highlight employee commitment is a measure of the willingness of employees to stay with a company in the future. This commitments reflect employees trust in the organization's mission and goals, willingness to do business in completing work, and the desire to continue working in the organization. Commitments are usually stronger among old employees, especially those who have experienced personal success in the organization. They work in committed teams. Employees who are committed to the organization usually have good attendance records, show voluntary loyalty to company policies, and have a low turnover rate.

There are three general behavioral indicators of employee commitment, namely (1) there is willingness to help colleagues complete organizational tasks, (2) unite their activities and priorities to achieve larger organizational goals, (3) choose needs appropriate organizations rather than following some professional interests.

According to Colquitt et al., employee commitment is

Revised Manuscript Received on April 19, 2019.

Pandapotan Sitompul, Lecturer Management Science, Sekolah Tinggi Ilmu Manajemen Saint Mary Jakarta, Indonesia.

Suparno Eko Widodo, Lecturer in Educational Management Department - Universitas Negeri Jakarta, Indonesia.

R. Madhakomala, Lecturer in Educational Management and Human Resource Mangement Departement - Universitas Negeri Jakarta, Indonesia. defined as desire of employees to continue to be members of the organization. Employee commitment affects whether employees endure being members of organizations or going to pursue other jobs. Employees who are not committed to the organization have self-withdrawal behavior, namely a set of actions that employees show to avoid behavioral work situations that usually trigger out of the organization (1).

Inanlou \& Ahn's research from Ewha Womans University, South Korea with the title Impact of Organizational Culture on Employee Commitments: Role of Mediation in Human Resource Development in Korean Companies: Commitment of workers is an important to increase employees' accomplishment. The rationale is the following. When what the employee feels part of the organization, such identification immediately contributes to fostering high degree commitment and innovation. Therefore, we expect organizational culture will enhance commitment of employees (2).

Based on the opinions above, worker commitment is important to improve employee performance. The rationale is as follows. When employees feel that they are part of an organization, such identification immediately contributes to encouraging high-level commitment and innovation. Therefore, it is expected that the organizational culture will increase employee commitment.

Porter stated organizational commitment has evolved from the past until now as a multi-dimensional construction to understand why employees remain or leave the organization. Transformational leadership has been studied in a limited way as an antecedent to organizational commitment, and the results of this study provide consistent results (3).

Based on the above opinion, organizational commitment has progressed from the past until now as multi-dimensional construction to understand the reasons why employees survive in the organization or leave the organization. Transformational leadership has been studied in a limited way as an antecedent for organizational commitment, and the results generally provide consistent results.

Njoroge et al., stated management literature is awash with evidence suggesting that organizational commitment is associated with variables of great importance for organizational efficiency and success. Transformational leadership is an important antecedent of organizational commitment (4). 
Based on the statement above, there is a lot of research in management that shows that organizational commitment is associated with variables that are very important for the purpose of efficiency and success of the organization. Transformational leadership is an important antecedent of organizational commitment.

Based on research conducted by the three researchers, it is known that organizational culture has an impact on employees commitment and leadership impact on employee commitment.

This research was conducted at PT Astra Agro Lestari Tbk, one among the promment private plantation companies in Indonesia. The real conditions at the research location were employees the private company, based on a preliminary survey with 30 employees, it was seen that employee commitment was still low.

Based on the background of the problem, identification of the problem, limitation of the problem, then formula problem of this study are as follows: (1) Is there a direct influence of work culture on employee commitment? (2) Is there a direct influence of leadership on employee commitment? (3) Is there a direct influence of work cuture and leadership together on employee commitment?

Based on the opinions above, it can be assumed that employee commitment is important to improve employee performance. This is because when employees feel that they are part of an organization then such identification immediately contributes to encouraging high-level commitment and innovation. Therefore, it is expected that the organizational culture will increase employee commitment.

Furthermore, human resources in the company play an important role in every success achieved by the company. These human resources are the driving force of the company's business wheels. Therefore, improving the quality of human resources through various development program activities becomes the company's main priority in providing opportunities for all employees to be able to develop their individual abilities while contributing to improving team work performance. Human resource development activities in the company focus on efforts to develop that is from amateurs to professionals. Human resources for the company are not just ordinary assets, but are strategic assets expected to create, empower and develop other systems and resources within the organization. In an effort to support the development of quality human resources, the company composes a human resource competency development program or Astra Agro Lestari Development Program which aims to form a positive culture for all of the company's human resources, so that they are ready to face any changes in the future. Based on the explanation above, the commitment of employes in the company is important to study because the employee commitment variable is one of the basic activities and one of the main objectives in the organization's efforts to maintain its existence and this is important for achieving the company's goals.

\section{LITERATURE REVIEW}

According Robbins S.P. "Organizational commitment is the degree to which an employee identifies with a particular organization and its goals and wishes to maintain a membership in an organization" (5). Furthermore Robbins stated that organizational commitment as a condition where a member sided with an organization and its goals, and was interested in maintaining membership in the organizational commitment is the loyalty of individuals to the organization. According Schermerhorn et al., organizational commitment is the loyalty of an individual to the organization (6). Thus, Schermerhorn briefly defined organizational commitment as individual loyalty to organization. This means that the higher a person's organizational commitment, the higher the level of pride of being a member of the organization, because the stronger he or she identifies him or herself with organization (7). Furthermore, organizational commitment is defined as the desire of the employee to remain be a member of the organization. Thus, their opinions are in line with previous opinions which make the defense aspect of a key feature in one's commitment to the organization. Therefore, someone who has a strong commitment to his or her organization makes it with a low level of absenteeism and he or she does not want to move to another place or organization.

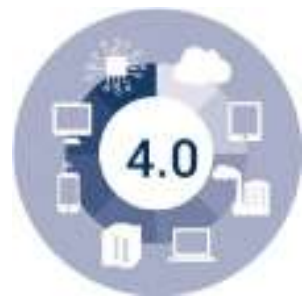

\section{Figure 1. Conditions for Revolution 4.0 Which are Supervised by Employees}

Moreover, the employee also has the willingness to sacrifice and even he or she has the pride of being a member of the organization. The more a person is committed to his or her organization, the greater his or her willingness to sacrifice which indicates high morale or works Accordingly, it can be synthesized that employee commitment is a desire and loyalty attitude (identification, involvement / attachment) that is shown by someone to organization that is by willing to be involved in carrying out the tasks or work to achieve organizational goals and desires and remain as members. The indicators are (1) emotional attachment to the organization; (2) self-identification of the organization; (3) rational attachment to the organization; (4) attachment due to the need for the organization; (5) moral attachment to the organization; and (6) loyalty to stay in the organization.

In simple terms, work culture look as the implementation of cultural concepts in work or in a group. As stated by Schein the following: The culture of groups are now interpreted as patterns of shared basic assumptions that groups learn when they solve problems of adjustment with external parties and their internal integration, that was works well so it is considered valid because it must thaught for new members as the right way to understand, thing and feel 
in connection with the problem that exists (8).

Based on the above opinion, the culture that develops in a group or organization is basic pattern of assumptions agreed upon, has been studied by group members in solving problems related to adjustments externally and internally integration. Culture develops because it has worked well so that it is which means valid therefore culture can taught for new members of the organization as right way to realize, think and feel relationships in dealing with group problems.

According to Nawawi, understanding of work culture is a habit that is carried out repeatedly by employees in an organization, violations of this practice are not strictly sanctioned, but morally organizational behavior has agreed that these habits are habits that must be adhered to in order to carry out work to achieve aim (9).

Whereas according to Prasetya, the notion of work culture is a philosophy based on the view of life as a value that becomes traits, habits, and the power that drives, rooted in life a community group or organization reflected in attitudes to behavior, ideals, beliefs, actions and opinions incarnate as work or work (10).

So work culture is an attitude and belief and trust from all members of organization in action that is real or working, because it contains values that form habits, and also is a strong encouragement.

In organizations, functions or goals of work culture are as social glue in uniting members in achieving organizational goals in the form of provisions or values that must be said and done by its members. In addition, work culture also functions as a control over behavior of members of the organization.

Tylor (in Ndraha), stated "Culture or civilization from a broad ethnographic is a very complex whole that covers beliefs, knowledge, morals, arts, customs, laws and abilities and other habits acquired by individuals as members society". It cannot be denied the opinion of Tylor. Because work culture always involves many things, knowledge, beliefs, art, morality, law, customs and capabilities and other habits. All of them have their respective roles as part of the community in an organization (11).

According to Ndraha, understanding of work culture is a group of basic thoughts or mental programs that can be used for improve work efficiency and human cooperation owned by a group of people.

Based on the explanation of the concept above, it can be synthesized that what is meant by understanding work culture is a system of values, perceptions, behaviors and beliefs held by each individual employee about the meaning of work and reflection in activities to achieve organizational goals. The indicators are 1) Hard work, 2) Discipline, 3) Productive, 4) Responsibility, 5) Creative, 6) Dynamic, and 7) Independent.

Colquitt et al. define leadership or leadership is the use of strength and influence in directing followers' activities to achieve goals (12). For them leadership is about a person's ability to use strength and influence on his followers to want to carry out their activities to achieve desired goals.

Stoner and Freeman say that leadership or leadership is art in coordination and motivating individuals and group to achieve the desired end (13). For them leadership is art in coordination and encouraging individuals or groups in achieving the expected goals. So, leadership means the process of how leaders are imaginatively governing, directing, guiding or influencing others in choosing and achieving certain goals.

Dlamini, said "transformational leadership occurs when the leader motivates, inspires and intellectually encourage subordinates with charismatic behavior and employees follow the steps in achieving organizational goals" (15). This means transformational leadership occurs when leaders motivate, inspire and intellectually stimulate subordinates to behave in charismatic ways and employees follow rules in achieving organizational goals.

By exposing the concept above, it can be synthesized that what is meant by leadership is a person's actions in influencing and directing a person or group of people by recognizing, supporting, training or developing, motivating or inspiring, fostering good relations, protecting and giving feedback to subordinates to be willing to work together in achieving goals set by the organization.

The indicators of leadership are (1) leadership actions in influencing and directing; (2) leadership clarity in delegating tasks; (3) ways to guide and establish and reinforce organizational policies; (4) how to guide its members in carrying out the organization's vision and mission; (5) how to provide input or advice in implementing policies; (6) activities in working both personally and in groups.

\section{METHODOLOGY}

This research was carried out for 1.5 years, starting in December 2016 until May 2018. In accordance with the problems and research objectives to be achieved, this research method uses a survey with a path analysis approach. The target unit in this study is the middle managerial level employee of the private company. The sample characteristics are (1) managerial employees at the middle manager level; (2) middle level manager employees who have worked in a plantation for a minimum of 5 years of work; (3) middle level manager employees with positions as head of department.

The total population of employees and at the same time as an affordable population are 143 people. To determine sample size, researchers used Slovin's formula technique. The level of precision is set at 0.05 or $5 \%$ of the total population of 143 middle level employees, a sample of 105 people is obtained.

The data of this research were obtained from respondents of the Head of Education (middle manager) as many as 105 (one hundred and five) people who filled in the statement items in accordance with the instrument consisting of 3 (three) variables, including: 2 (two) independent variables: Work Culture $\left(\mathrm{X}_{1}\right)$, Leadership $\left(\mathrm{X}_{2}\right)$ and 1 (one) dependent variable: Employee Commitment (Y).

This study uses regression analysis. The data obtained from 105 (one hundred and five) respondents consists of 31 valid statements from 32 existing statements, with a maximum score range from 135 and a minimum value of 96. The mean $=118.08$, mode $=116$, median $=119.00$, 
standard deviation $=8.79$, and variance $=77.23$. The frequency distribution of employee commitment of variable data distribution is in table 1 below.

Table 1. Distribution of Frequency of Employee Commitments (Y)

\begin{tabular}{|c|c|c|c|c|c|c|}
\hline \multirow[b]{2}{*}{ No. } & \multirow{2}{*}{$\begin{array}{l}\text { Interval } \\
\text { Class }\end{array}$} & \multirow[b]{2}{*}{ Lower Limit } & \multirow{2}{*}{$\begin{array}{l}\text { Upper } \\
\text { Limit }\end{array}$} & \multicolumn{3}{|c|}{ Frequency } \\
\hline & & & & Absolute & $\begin{array}{l}\text { Relative } \\
\text { (\%) }\end{array}$ & $\begin{array}{l}\text { cumulative } \\
\text { (9) }\end{array}$ \\
\hline 1 & $96-100$ & 95,5 & 100.5 & 4 & 3.81 & 3.81 \\
\hline 2 & $101-105$ & 100,5 & 105.5 & 6 & 5,71 & 9,52 \\
\hline 3 & $106-110$ & 105,5 & 110.5 & 10 & 9,52 & 19,05 \\
\hline 4 & $111-115$ & 110,5 & 115,5 & 17 & 16,19 & 35,24 \\
\hline 5 & $116-120$ & 115,5 & 120.5 & 22 & 20.95 & 56,19 \\
\hline 6 & $121-125$ & 120,5 & 125,5 & 27 & 25,71 & 81,90 \\
\hline 7 & $126-130$ & 125,5 & 130,5 & 11 & 10,48 & 92,38 \\
\hline 8 & $131-135$ & 130,5 & 135,5 & 8 & 7,62 & 100,00 \\
\hline \multicolumn{2}{|c|}{ Total } & & & 105 & 100,00 & \\
\hline
\end{tabular}

The data obtained from respondents consisted of 27 valid statements from 30 items, with a maximum score of 124 and a minimum score of 77 . Thus, the mean socre $=102.51$, mode $=96$, median $=102,00$, standard deviation $=11,524$, and variance $=132,810$. The frequency distribution of the data distribution of the Work Culture variable is shown in table 2 below.

Table 2. Distribution of Frequency of Work Culture $\left(\mathbf{X}_{1}\right)$

\begin{tabular}{|c|c|c|c|c|c|c|}
\hline \multirow[b]{2}{*}{ No. } & \multirow{2}{*}{$\begin{array}{l}\text { Interval } \\
\text { Class }\end{array}$} & \multirow{2}{*}{$\begin{array}{l}\text { Lower } \\
\text { Limit }\end{array}$} & \multirow{2}{*}{$\begin{array}{l}\text { Upper } \\
\text { Limit }\end{array}$} & \multicolumn{3}{|c|}{ Frequency } \\
\hline & & & & Absolute & $\begin{array}{l}\text { Relative } \\
(\%)\end{array}$ & $\begin{array}{l}\text { Cumulative } \\
\text { (\%) }\end{array}$ \\
\hline 1 & $77-82$ & 76,5 & 82,5 & 4 & 3,81 & 3,81 \\
\hline 2 & 83.88 & 82,5 & 88.5 & 8 & 7.62 & 11,43 \\
\hline 3 & 89.94 & 88,5 & 94,5 & 15 & 14,29 & 25,71 \\
\hline 4 & $95-100$ & 94,5 & 100,5 & 18 & 17,14 & 42,86 \\
\hline 5 & $101-106$ & 100,5 & 106,5 & 20 & 19,05 & 61,90 \\
\hline 6 & $107-112$ & 106,5 & 112.5 & 17 & 16,19 & 78,10 \\
\hline 7 & $113-118$ & 112,5 & 118,5 & 13 & 12,38 & 90,48 \\
\hline 8 & $119-124$ & 118,5 & 124,5 & 10 & 9,52 & 100,00 \\
\hline \multicolumn{2}{|c|}{ Total } & & & 105 & 100,00 & \\
\hline
\end{tabular}

The data obtained from respondents consisted of 28 valid statements from 32 items with a Likert scale of 1 to 5 , a maximum score of 132 and a minimum score of 65 , so that the mean $=99.84$ was obtained, mode $=102$, median $=$ 102.00, standard deviation $=14,120$ and variance $=199,368$. The frequency distribution of the data distribution of the Attitude of Leadership variable is shown in the following table 3 .

Table 3. Leadership Frequency Distribution $\left(\mathbf{X}_{2}\right)$

\begin{tabular}{|c|c|c|c|c|c|c|}
\hline \multirow[b]{2}{*}{ No. } & \multirow{2}{*}{$\begin{array}{l}\text { Interval } \\
\text { Class }\end{array}$} & \multirow{2}{*}{$\begin{array}{l}\text { Lower } \\
\text { Limit }\end{array}$} & \multirow{2}{*}{$\begin{array}{l}\text { Upper } \\
\text { Limit }\end{array}$} & \multicolumn{3}{|c|}{ Frequency } \\
\hline & & & & Absolute & $\begin{array}{l}\text { Relatice } \\
(\%)\end{array}$ & cumulative $(\%)$ \\
\hline 1 & $65-73$ & 64,5 & 73,5 & 4 & 3,81 & 3,81 \\
\hline 2 & 7482 & 73,5 & 82,5 & 9 & 8.57 & 12,38 \\
\hline 3 & $83-91$ & 82,5 & 91,5 & 16 & 15,24 & 27,62 \\
\hline 4 & $92-100$ & 91,5 & 100,5 & 20 & 19,05 & 46,67 \\
\hline 5 & $101-109$ & 100,5 & 109,5 & 27 & 25,71 & 72,38 \\
\hline 6 & $110-118$ & 109,5 & 118,5 & 21 & 20,00 & 92,38 \\
\hline 7 & $119-127$ & 118,5 & 127,5 & 6 & 5,71 & 98,10 \\
\hline 8 & $128-136$ & 1275 & 136,5 & 2 & 190 & 100,00 \\
\hline \multicolumn{2}{|c|}{ Total } & & & 105 & 100,00 & \\
\hline
\end{tabular}

In summary the above theoretical framework can be described in the following scheme:

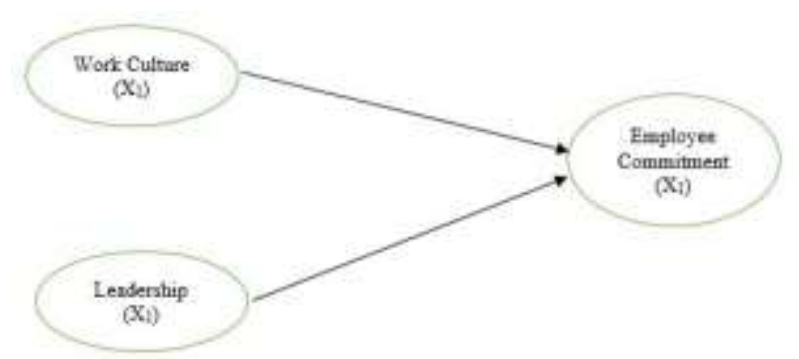

Figure 2. Theoretical Framework of Research Variables

\section{Research Hypothesis}

Based on the formulation of problem and the theoretical framework, the research hypothesis can be formulated as follows:

1. There is direct effect of work culture on employee commitment

2. There is direct effect of personality on employee commitment

3. There is a direct effect of work culture and leadership together on employee commitment

Basic Assumption Test

Normality test

Table 4 Normality Test

Tests of Normalty

\begin{tabular}{|c|c|c|c|c|c|c|}
\hline & \multicolumn{3}{|c|}{ Ksmoyros Snings } & \multicolumn{3}{|c|}{ Shasin-king } \\
\hline & Strisर: & t & sh & Seast: & d & sis. \\
\hline Y.Enylues Cinn tnents & 172 & 105 & $2200^{\circ}$ & set & 105 & 221 \\
\hline Xivaricuhrit) & 144 & 105 & $200^{\circ}$ & 563 & 105 & 189 \\
\hline QLeastertof & If66 & 105. & $200^{\circ}$ & 969 & 195 & 564 \\
\hline
\end{tabular}

This is a hwe thund oftte tue sigiviance.

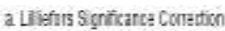

From the table 4 we see in the Kolmogorov-Smirnov column and it can be seen that the significance value for Work Culture $\left(\mathrm{X}_{1}\right)$, Personality $\left(\mathrm{X}_{2}\right)$ and Employee Commitment $(\mathrm{Y})$ is 0.200 . Because the significance for all variables is greater than 0.05 , it can be concluded that data population is Work Culture $\left(\mathrm{X}_{1}\right)$, Leadership $\left(\mathrm{X}_{3}\right)$ and Employee Commitment (Y) with normal distribution.

Linearity Test

Table 5 Linearity Test $\mathrm{Y}-\mathrm{X}_{1}$ Moitate

\begin{tabular}{|c|c|c|c|c|c|c|c|}
\hline & & & Sortsame & t & Hasant & $f$ & \$s \\
\hline \multirow{5}{*}{ 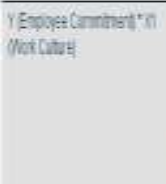 } & \multirow[t]{3}{*}{ Ather fonas: } & Desurat & se264 & 49 & 5,60 & $1 \%$ & $g$ \\
\hline & & Lreat & mase & 1 & 1T215 & 3014 & I. \\
\hline & & Didntenivan & resses & 42 & 5111 & $\pi n$ & 로 \\
\hline & atobass & & 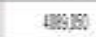 & at & 매연 & & \\
\hline & Tit & & 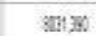 & \% & & & \\
\hline
\end{tabular}

From the table 5, the linearity test results can be seen in ANOVA Table output. It can be seen the significance value of linearity is 0,000 . Because the significance is less than 0.05 , the variable between employee commitment and work culture has a linear relationship. 
Table 6 Linearity Test $\mathrm{Y}-\mathrm{X}_{2}$

\begin{tabular}{|c|c|c|c|c|c|c|c|}
\hline \multicolumn{8}{|c|}{ HXITde } \\
\hline & & & Santhas: & t & larhes: & $\neq$ & 5 \\
\hline \multirow{5}{*}{ 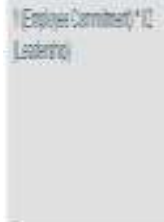 } & \multirow[t]{3}{*}{ batelises: } & baverh & 324] & is & $111 \pi$ & 148 & I8 \\
\hline & & [ent & Won: & 1 & wy & 38 & : \\
\hline & & Dirintumerin & HESW & H & 4hn & 10:5 & 被 \\
\hline & Finats & & $3 M$ & 5 & 15e & & \\
\hline & TH & & 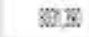 & 1. & & & \\
\hline
\end{tabular}

From table 6, the linearity test results can be seen in ANOVA Table output. It can be seen the significance value of linearity is 0,000 . Because the significance is less than 0.05 , there is a linear relationship between employee commitment and leadership variable.

\section{Hypotheses Test}

Based on data processing using IBM SPSS Statistics 22, the output for regression analysis is obtained as shown in table 7 below.

Table 7. Multiple Regression Analysis of Work Culture $\left(X_{1}\right)$ and Leadership $\left(X_{2}\right)$ on Employee Commitments (Y).

\begin{tabular}{|c|c|c|c|c|c|c|}
\hline \multicolumn{7}{|c|}{ Coefficients $^{\mathrm{a}}$} \\
\hline \multirow[b]{2}{*}{ Yodel } & & \multicolumn{2}{|c|}{ Usstentardead Couficiarts } & \multirow{2}{*}{$\begin{array}{c}\text { Shandarted } \\
\text { Coeficents } \\
\text { Btts }\end{array}$} & \multirow[b]{2}{*}{$t$} & \multirow[b]{2}{*}{ Sis. } \\
\hline & & $B$ & Str. Enor & & & \\
\hline \multirow[t]{3}{*}{1} & [Constarti] & 65996 & 7,893 & & $B, 364$ & 000 \\
\hline & Xt (mox cutures) & 392 & 103 & 435 & 5,227 & 000 \\
\hline & Xe(teadaraip) & .182 & .052 & 252 & 3,509 & 001 \\
\hline
\end{tabular}

a. Positive Direct Effect of Work Culture $\left(\mathrm{X}_{1}\right)$ on Employee Commitment (Y)

To prove that Work Culture $\left(\mathrm{X}_{1}\right)$ has a positive direct effect on Employee Commitment (Y), the hypotheses tested are as follows:

$\mathrm{H}_{0}: \beta \mathrm{Y} 1 \leq 0$

$\mathrm{H}_{1}: \beta \mathrm{Y} 1>0$

Based on the calculation of path coefficients using SPSS 25 as shown in the table. The value of $\beta Y 1=0,435$, with sig $=0,000$. Because sig $0,000<0,05$, then $\mathrm{H}_{0}$ is rejected, this means that work culture $\left(\mathrm{X}_{1}\right)$ has a positive direct effect on employee commitment (Y).

b. Positive Direct Effect of Leadership $\left(\mathrm{X}_{2}\right)$ on Employee Commitment (Y)

To prove that Leadership $\left(\mathrm{X}_{2}\right)$ has a positive direct effect on Employee Commitment ( $\mathrm{Y})$, the hypotheses tested are as follows:

$$
\mathrm{H}_{0}: \beta Y 2 \leq 0
$$

$\mathrm{H}_{1}: \beta \mathrm{Y} 2>0$

Based on the results of the calculation of path coefficients in the obtained value of $\beta Y 2=0.292$ with sig $=0.001$. Because sig $0.001<0.05$, then $\mathrm{H} 0$ is rejected, this means leadership $\left(\mathrm{X}_{2}\right)$ has a positive direct effect on employee commitment $(\mathrm{Y})$

Based on data processing using IBM SPSS Statistics 25, the output for multiple regression analysis was obtained to influence jointly work culture $\left(\mathrm{X}_{1}\right)$ and leadership $\left(\mathrm{X}_{2}\right)$ on employee commitment (Y) as shown in table 8 below.

Table 8. Coefficient of Determination of the Influence of Joint Work Culture $\left(X_{1}\right)$ and Leadership $\left(X_{2}\right)$ toward Employee Commitment (Y)

Model Summary

\begin{tabular}{rr|r|r|r} 
Model & $R$ & R Square & \multicolumn{1}{c}{$\begin{array}{c}\text { Adjusted R } \\
\text { Square }\end{array}$} & $\begin{array}{l}\text { Std. Error of } \\
\text { the Estimate }\end{array}$ \\
\hline 1 &, $550^{\text {a }}$ &, 302 &, 289 & 7,411 \\
\hline \multicolumn{2}{l}{ a. Predictors: (Constant), X2 (Leadership), X1 (Work Culture) }
\end{tabular}

Table 9. Influence Together Work Culture $\left(X_{1}\right)$ and Leadership ( $\left.\mathbf{X}_{2}\right)$ Against Employee Commitment (Y)

\begin{tabular}{|c|c|c|c|c|c|c|}
\hline \multicolumn{7}{|c|}{ ANOVA $^{\mathrm{a}}$} \\
\hline \multicolumn{2}{|l|}{ Model } & $\begin{array}{l}\text { Sum of } \\
\text { Squares }\end{array}$ & of & Hean Square & $F$ & Sig. \\
\hline \multirow[t]{3}{*}{1} & Regression & 2428,708 & 2 & 1214,354 & 22,108 &, $000^{b}$ \\
\hline & Residual & 5602,683 & 102 & 54,928 & & \\
\hline & Total & 8031,390 & 104 & & & \\
\hline
\end{tabular}

From table 9, it can be seen that the determination correlation coefficient ( $\mathrm{R}$ Square) is 0.302 (30.2\%). This means that the formation of $30.2 \%$ employee commitment is influenced by work culture and leadership, while the remaining was $69.8 \%$ of employee commitment which is influenced by other factors besides work culture and leadership that were not examined in this study. From table 6 , it can be seen the sig value $=0,000$. Because sig 0,000 $<0,05$, it can be concluded that there is an influence of work culture and leadership together on employee commitment.

\section{RESULT AND FINDINGS}

Leadership refers to person's actions in influencing and directing a person or group of people by recognizing, supporting, training or developing, motivating or inspiring, fostering good relations, protecting, and giving feedback to subordinates to work together in order to achieve the goals set by the organization. The indicators of leadership are (1) leadership actions in influencing and directing; (2) leadership clarity in delegating tasks; (3) ways to guide and determine and reinforce organizational policies; (4) how to guide his or her members in carrying out the organization's vision and mission; (5) how to provide input or advice in implementing policies; (6) activities in working both personally and in groups.

The Influence of Leadership on Employee Commitment is as stated by Colquitt et al. that "transformational leadership has a strong positive effect on commitment". The Leadership has a strong positive influence on employee commitment. There is the influence of leadership on improving performance through the path-goal theory. 
leaders can be effective because of their influence on employee motivation. Besides, leaders can generate performance and employee satisfaction. This theory is called path-goal because attention is primarily placed on how to influence employee perceptions in achieving their goals, personal goals, and ways or paths in achieving these goals, so as to increase their commitment to the organization.

Furthermore, based on the results of hypothesis testing, it is found that the influence of work culture on employee commitment is 0.435 or $43.5 \%$. This is supported by Robbins who states that work culture is a causal variable of changes in the dependent variable of employee commitment so that work culture increases employee commitment and consistency of member behavior (5). The results of this study are also supported by the results of a study conducted by Nongo et al. (2012), shows the results of the Pearson correlation between independent variables (involvement, consistency, adaptability and mission) and the dependent variable (employee commitment) has a positive relationship between commitment and involvement $(\mathrm{r}=.179, \mathrm{p}<.05)$. Likewise, there is a positive and significant relationship between adaptability and commitment $(r=0.233, p<.01)$ (Nongo et al., 2012).

Basically, leadership refers to a person's actions in influencing and directing a person or group of people by recognizing, supporting, training or developing, motivating or inspiring, fostering good relations, protecting, and giving feedback to subordinates to work together to achieve their intended goals by the organization. The factors that support leadership must be managed well in an organization. Likewise, with the Company organization as one of the companies engaged in the business of oil palm plantations in Indonesia. In this study, the hypothesis to prove leadership influences employee commitment to the Company. From the results of, it shows that leadership has a positive direct effect on employee commitment.

Based on the results of hypothesis testing, the effect of leadership on employee commitment is 0.292 or $29.2 \%$. This is supported by Colquitt et al. (2009) stating "transformational leadership has a strong positive effect on commitment" (16) Leadership has a strong positive influence on employee commitment. The results of this study are also reinforced by research conducted by Joo, B. (2012) who provides an illustration that there is a relationship between transformational leadership and organizational commitment $(r=0.270$ at $\alpha=0.05)$.

The results of this research, in line with the opinion of Schein (2004) who said that work culture influences employee commitment, Dlamini (2017) research said that there was an influence of leadership on employee commitment.

\section{CONCLUSION}

Based on the analysis, the findings in this study are as follows:

1. There is a positive direct effect of work culture on employee commitment, meaning that if the work culture increases, then employee commitment will also increase.

2. There is a positive direct influence of leadership on employee commitment, meaning that if leadership increases, the employee commitment will also increase.
3. There is a direct influence of work culture and leadership together on employee commitment meaning that if the work culture and leadership increases, then employee commitment will also increase.

\section{ACKNOWLEDGMENT}

PT Astra Agro Lestari Tbk and Sulfikar Sallu ID Scopus 57200989289 doctoral students of Education Technology, Jakarta State University, and Lecturer at the Faculty of Information Technology, Universitas Sembilanbelas November, Kolaka Southeast Sulawesi Indonesia.

\section{REFERENCES}

1. Colquitt et al. Organizational Behavior: Improving Performance and Commitment in the Workplace. New York: McGraw-Hill; 2009. 67 p.

2. Inanlou \& Ahn. The Effect Of Organizational Culture On Employee Commitment: A Mediating Role Of Human Resource Development In Korean Firms. J Appl Bus Res. 2017;33(1):88.

3. Porter JA. The relationship between transformational leadership and organizational commitment in nonprofit long term care organizations: The direct care worker perspective. Creight $\mathrm{J}$ Interdiscip Leadersh. 2015;1(2):68-85.

4. Njoroge et al. Transformational Leadership Style and Organizational Commitment: The Moderating Effect of Employee Participation. Srategic J Bus Chang Manag. 2015;2(6):94-107.

5. Robbins SP. Organizational Behaviour. 8th ed. USA: Prentice Hall; 2000. 28-33, 726 p.

6. Schermerhorn et al. Organizational Behavior. New Jersey: John Wiley \& Sons, Inc.; 2010. 72 p.

7. Schermerhorn et al. Organizational Behavior. New York: John Wiley \& Sons, Inc.; 2010. 306 p.

8. Schein E. Organizational Culture and Leadership. San Fransisco: John Wiley \& Sons, Inc.; 2004. 17 p.

9. Nawawi H. Human Resource Management. Yogyakarta: Gadjah Mada University Press; 2003. 65 p.

10. Prasetya T. Manajemen Sumber Daya Manusia. Jakarta: Bumi Aksara; 2001. 13 p.

11. Ndraha $T$. Introduction to the Theory of Human Resource Development. Bandung: Rosdakarya; 1997. 76 p.

12. Colquitt et al. Organizational Behavior: Improving Performance and Commitment in the Workplace. New York: McGraw-Hill; 2015. 441 p.

13. Stoner et al. Management. New Jersey: Prentice Hall $1995.43 \mathrm{p}$

14. Stoner JA. and FE. Management. New Jersey: Prentice Hall; $1995.43 \mathrm{p}$

15. Dlamini NNN et al. The impact of transformational leadership style on organisational commitment in the hospitality industry. African J Hosp Tour Leis. 2017;6(3):3.

16. Colquitt et al. Organizational Performance and Commitmen in the Workplace. New York: McGraw-Hill; 2009. 486 p. 


\section{AUTHORS PROFILE}

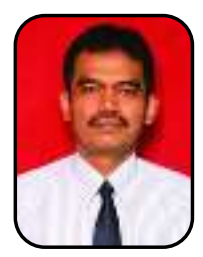

Pandapotan Sitompul Undergraduate Universitas Sumatera Utara Medan, Postgraduate (Master) Management IPWI Jakarta, Postgraduate (Doctoral Degree) in Management Science - Human Resources Management Universitas Negeri Jakarta, Lecturer Management Science, Sekolah Tinggi Ilmu Manajemen Saint Mary Jakarta.Email: pandapotan.sitompul3064@gmail.com

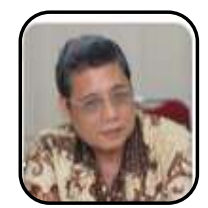

Suparno Eko Widodo Undergraduate - Universitas Negeri Malang, Postgraduate (Master and Doctoral) Universitas Negeri Jakarta, Lecturer in Educational Management Department - Universitas Negeri Jakarta.

Email: suparnoeko@unj.ac.id

SINTA ID: 6031998.

R. Madhakomala Undergraduate - Postgraduate (Master and Doctoral) - Universitas Negeri Jakarta, Lecturer in Educational Management and Human Resource Mangement Departement - Universitas Negeri Jakarta. Email: madhakomala@unj.ac.id SINTA ID: 6024105. 